Synthesis, part of a Special Feature on Local, Social, and Environmental Impacts of Biofuels

\title{
Local Social and Environmental Impacts of Biofuels: Global Comparative Assessment and Implications for Governance
}

\author{
Laura German $^{1,2}$, George C. Schoneveld ${ }^{1}$, and Pablo Pacheco ${ }^{1}$
}

\begin{abstract}
The 2000s witnessed the rapid expansion of biofuel plantations in the global South in the context of a growing trend of crop plantation expansion. This trend has been spurred by policies in the European Union, United States, Brazil, and other countries favoring the use of biofuels in the transport sector to enhance energy security and reduce carbon emissions, as well as by the desire of governments in developing countries to harness the stimulus that new commercial investments provide to the agricultural sector and to national economies. Despite these potential benefits, a number of concerns have been raised about the local social and environmental impacts of biofuel feedstock expansion. We shed light on this debate through a synthesis of findings from case studies in six biofuel producer countries of Asia, Africa, and Latin America, and a seventh paper exploring the implications of the land-use changes observed in these case studies for the climate mitigation potential of biofuels. We also explore the implications for governing the environmental impacts of biofuel feedstock production, protecting the rights of customary land users, and enabling smallholder-inclusive business models. Our analysis suggests that better governance of the sector's impacts is not the exclusive preserve of unitary sets of actors, but instead requires concerted and coordinated efforts by governments of producer and consumer countries, investors, civil society, and the financial sector to better capture the sector's potential while minimizing its social and environmental costs.
\end{abstract}

Key Words: biofuels; developing countries; environmental impacts; global South; social impacts

\section{INTRODUCTION}

The last decade has witnessed the rapid expansion of biofuel plantations in the global South, in the context of a growing trend of crop plantation expansion, mainly of oilseeds. This trend has been spurred by policies in the European Union, USA, Brazil, and other countries favoring the use of biofuels in the transport sector to enhance energy security and reduce carbon emissions, as well as by the desire of governments in developing countries to harness the stimulus that new commercial investments could provide to the agricultural sector and to national economies (Republic of Mozambique 1997, Johnson and Rosillo-Calle 2007, U.S. Congress 2007, European Commission 2009). Despite these potential benefits, this trend raises a number of concerns, particularly in the developing country context. An unwavering faith in the potential of industrial-scale agriculture and foreign (and domestic) direct investment to drive economic development has led many governments to provide generous incentives to attract investors and facilitate their access to land (Schoneveld and German 2010, de Andrade and Miccolis 2011, German and Schoneveld in press). In many countries, market conditions and government policies, particularly fiscal incentives, tend to favor the large-scale plantation agricultural and agribusiness sectors, often with limited public support to enable smallholders to overcome barriers to market entry.

Land-use change to biofuel feedstock production is also fraught with undesirable trade-offs and often is subject to conflicting policy objectives. In sub-Saharan Africa and Southeast Asia, national plantation expansion and blending targets and efforts to minimize negative effects on food security have led to the targeting of forests, woodlands, and so-called degraded lands for biofuel expansion (Koh and Wilcove 2008, Schoneveld et al. 2011). Although this type of land-use change can often be justified on purely economic terms, converting carbon-rich forests, woodlands, and rangelands risks undermining the climate mitigation potential of biofuels while simultaneously displacing land uses that are of high value to the local population for food, income, and safety net functions (Colchester et al. 2006, Reijnders and Huijbregts 2008, Romijn 2011). Conversely, regulations to reduce carbon emissions among large consumers, e.g., the European Renewable Energy Directive, encourage some producers to target areas with low carbon stock densities. However, this increases the risk of displacement for smallscale farmers and pastoralists occupying these lands, potentially undermining food security. In Latin America, direct and indirect impacts of biofuel development are justifying the need to target degraded lands, which are often cattle ranching operations of low productivity; it is uncertain, however, what incentives will be put in place to promote this shift, as well as the likely implications to existing landholders (Sawyer 2008). These tensions have stimulated highly polarized and largely unresolved debates about the merits of biofuels, with assumptions often driving decisions on economic development pathways that carry high stakes for rural communities and society at large.

The papers in this special feature aim to contribute to this debate by highlighting the social and ecological consequences 
of biofuel feedstock expansion in 12 landscapes in six countries of the global South: Brazil, Ghana, Indonesia, Malaysia, Mexico, and Zambia. Our analysis focuses on the expansion of both feedstocks with a primary orientation to the biofuel market and multi-purpose feedstocks destined for different end uses (e.g., food, fuel, feed) but for which lessons are directly applicable to the expanding biofuel industry. Drawing on a diversity of case studies covering diverse feedstocks (oil palm, soy, jatropha), ecoregions (humid tropical forests, dry woodlands), and business models (industrial scale, smallholder oriented), we explore the impacts and trade-offs associated with the cultivation of biodiesel and multi-purpose feedstocks. Although the number of case studies is limited and should not be interpreted as representative of either the countries from which they are derived or the industry at large, they do provide preliminary evidence that the economic and ecological promises of biofuels are often elusive and that highly uneven local livelihoods impacts are the norm. We summarize the findings from six country cases and a paper synthesizing the climate implications of observed land-use changes and conclude by exploring the implications of findings for the governance of investments, land, and the environmental and social impacts induced by agro-industrial expansion.

\section{EVIDENCE FOR THE LOCAL ENVIRONMENTAL AND SOCIAL IMPACTS OF BIOFUELS}

\section{Environmental impacts}

A key impetus behind the expansion of biofuel feedstocks is the potential to mitigate climate change. The extent to which biofuel expansion is contributing to direct and indirect deforestation, and the implications of land-use change for the potential of biofuels to mitigate climate change, are therefore of fundamental importance. This is particularly true given recent evidence of the significance of indirect land-use change for life cycle carbon emissions through both the displacement of local land uses and changes in global pricing (Searchinger et al. 2008, Lapola et al. 2010, Plevin et al. 2010). This runs counter to the early assumption that biofuels will by definition reduce greenhouse gases when substituting for fossil fuels because carbon is sequestered through feedstock cultivation (Plevin et al. 2010). Such impacts are also critical because one of the underlying motivations of biofuel programs in most of the case study countries, as well as a requirement of key consumer markets, is the reduction in carbon emissions (European Commission 2009, Chin 2011, Romero-Hernández et al. 2011, German and Schoneveld in press). Employment of the degraded land narrative to justify biofuel expansion into secondary forests and woodlands must also be scrutinized from an environmental perspective.

Land-use change: case study findings

Although an explicit attempt was made to identify landscapes with multiple business models, the ability to identify such landscapes and the early stage of development of certain business models often limited our choices. This resulted in a larger number of cases profiling industrial-scale plantations than smallholder schemes.

In cases involving industrial-scale business models, the expansion of multi-purpose feedstocks was found to be directly associated with deforestation in most case study sites (Table 1). It should be noted that the Mato Grosso case is an outlier in terms of the methods used to assess land cover change in that the analysis drew from published literature, rather than from an analysis of land cover data, and thus produced results that are regional in scope, rather than restricted to a particular plantation or investment. Findings suggest that the proportion of biofuel feedstock expansion that occurred at the expense of forests ranged from 13 to $99 \%$, with the highest rates observed for oil palm in Indonesia. It should be noted that the proportion of deforestation that may be attributable to the biofuel sector per se is far less than this at present for oil palm and soybean because of the multi-purpose nature of these crops and the predominance of production oriented to the food and feed industries. Nevertheless, these findings clearly illustrate the risks associated with these crops should they be used as feedstock for an expanding biofuel market. The case of Mato Grosso, where the lowest levels of deforestation are observed, is interesting for its illustration of how effective governance of the sector can reduce environmental impacts. A combination of stringent government regulations on forest conversion established in the Forest Code of 1964, the use of satellite imagery to monitor compliance, and a 2006 moratorium on soybeans grown in newly deforested areas have gone a long way to minimize forest conversion associated with direct land-use change in the context of agricultural expansion (Andrade and Miccolis 2011).

Whereas some of the cases illustrate the expansion of biofuel feedstocks into secondary forest and fallow, genuinely degraded land was not targeted for cultivation in any of the cases. This is in part because of the research emphasis on the biofuel-forest nexus, which privileged feedstock grown in forest and woodland ecoregions. Yet the finding that significant deforestation often accompanies biofuel feedstock expansion is not just an artifact of case study selection. Producer country governments and industry alike have actively sought forests and woodlands for agroindustrial expansion to minimize negative effects on food security, avoid the challenges associated with land appropriation and resettlement, and maximize timber revenues (Casson 1999, Holmes 2002, Valentino 2011, German and Schoneveld in press, Obidzinski et al. unpublished manuscript). Furthermore, negative stigma associated with traditional landuse practices involving itinerancy and fire (e.g., shifting agriculture, pastoralism, and charcoal burning) and assumptions about their ecological impacts have long served to justify the appropriation of customary lands and forests, not only by industry, but also by government (Dove 1983, 1993, Fairhead and Leach 1996, Kull 2004, German et al. 2011). 
Table 1. Summary of direct land-use changes associated with industrial-scale feedstock expansion in the case study sites.

\begin{tabular}{|c|c|c|c|c|c|c|}
\hline $\mathrm{Site}^{\dagger}$ & $\begin{array}{l}\text { Year operations } \\
\text { began }\end{array}$ & $\begin{array}{c}\text { Land or } \\
\text { concession area } \\
\text { secured } \\
\text { (ha) } \\
\end{array}$ & $\begin{array}{l}\text { Area developed } \\
\text { (ha) }\end{array}$ & $\begin{array}{c}\text { Area deforested } \\
\text { (ha) }\end{array}$ & $\begin{array}{c}\text { Feedstock } \\
\text { expansion causing } \\
\text { forest loss } \\
(\%) \\
\end{array}$ & Forest type \\
\hline $\begin{array}{l}\text { Brazil: Mato Grosso } \\
\text { State }\end{array}$ & Various & Various & $\begin{array}{l}5,075,079 \\
\text { (by 2007) }\end{array}$ & $\begin{array}{c}540,000 \\
(2001-2004)\end{array}$ & $13-18^{i}$ & Dry forest (cerrado) \\
\hline $\begin{array}{l}\text { Ghana: Pru District, } \\
\text { Brong Ahafo }\end{array}$ & 2008 & 14,500 & $\begin{array}{c}780 \\
\text { (by } 2010 \text { ) }\end{array}$ & $\begin{array}{l}379 \text { forest, } 240 \text { fallow } \\
\text { (by 2010) }\end{array}$ & $\begin{array}{c}47 \\
\text { (77 including } \\
\text { fallow) }\end{array}$ & $\begin{array}{c}\text { Dry forest (forest- } \\
\text { savannah transition zone) }\end{array}$ \\
\hline $\begin{array}{l}\text { Indonesia: Kubu } \\
\text { Raya, West } \\
\text { Kalimantan }\end{array}$ & 1994 & 13,605 & 5,350 & $\begin{array}{c}4,949^{\mathbb{I I}} \\
\text { (as of May 2009) }\end{array}$ & 94 & $\begin{array}{l}\text { Secondary peat swamp } \\
\text { forest }\end{array}$ \\
\hline $\begin{array}{l}\text { Indonesia: } \\
\text { Manokwari, West } \\
\text { Papua }\end{array}$ & 1982 & 12,049 & 10,207 & $\begin{array}{c}5,260^{\mathrm{II}} \\
\text { (as of Jun/Aug 2006) }\end{array}$ & 96 & $\begin{array}{l}\text { Primary humid tropical } \\
\text { rain forest }\end{array}$ \\
\hline $\begin{array}{l}\text { Indonesia: Boven } \\
\text { Digoel, Papua }\end{array}$ & 1998 & 34,000 & 18,804 & $\begin{array}{c}20,709^{\mathrm{q}} \\
\text { (as of Dec 2008) }\end{array}$ & 99 & $\begin{array}{l}\text { Primary humid tropical } \\
\text { rain forest }\end{array}$ \\
\hline Malaysia: Sabah & 1987 & $6,861^{\#}$ & 6,861 & 5,329 & 75 & $\begin{array}{l}\text { Scrub forest and logged } \\
\text { forest }\end{array}$ \\
\hline Mexico: Yucatán & 2007 & $\begin{array}{l}12,000 \\
(2009) \\
\end{array}$ & $\begin{array}{r}2,350 \\
(2009) \\
\end{array}$ & \multicolumn{2}{|c|}{ Unavailable $^{\dagger \dagger}$} & $\begin{array}{c}\text { Secondary dry forest } \\
\text { (acahual) }\end{array}$ \\
\hline
\end{tabular}

Land-use change data for Mato Grosso encompass two of the research sites: Sorriso and northern Mato Grosso (Guarantã do Norte/Alta Floresta). Similar data are unavailable for the Santarem site.

${ }^{*}$ With the exception of Ghana, only a portion of this area is from the biofuel industry; much of oil palm and soybean production is destined for food and feed markets.

${ }^{\S}$ This case is unique in capturing trends within an entire state rather than a specific plantation investment.

'This is the total due to soy expansion, but the authors estimate between 0.8 and $5.9 \%$ to be attributable specifically to the biodiesel component, depending on the food-fuel allocation approach used (Lima et al. 2011).

"These figures correspond with oil palm-induced deforestation; total deforestation was found to be 7100,6833 , and 36,666 ha, respectively, in the three sites (Obidzinski et al. unpublished manuscript).

${ }^{\#}$ Area figures are for Sapi 1 and Sapi 2 estates; total landholdings of PPB Wilmar are about three times this.

"This analysis was attempted but is left unreported because of the high level of patchiness of the displaced vegetation, the difficulties of clearly differentiating vegetation at different stages of regeneration, and the uncertainties therefore introduced in producing an unambiguous land cover classification.

Sources: Achten and Verchot 2011, German et al. 2011a, Lima et al. 2011, Schoneveld et al. 2011, Skutsch et al. 2011, Dayang Norwana et al. in press, Obidzinski et al. unpublished manuscript.

Finally, investors in some case study sites declared the impossibility of explicitly targeting degraded lands because of the profit motive. This illustrates the very real challenges of finding contiguous areas of truly degraded land within forest-rich landscapes and getting producers to focus exclusively on these areas.

Direct and indirect land-use changes were also observed under smallholder feedstock cultivation, with biofuel feedstock displacing variable proportions of permanent cropland (annuals and perennials, irrigated and rainfed), fallow, and mature forest. For the one smallholder case in which land-use change associated with smallholder systems was assessed (jatropha in Zambia), significant deforestation was found to occur. With $22 \%$ of respondents claiming to have opened up mature forests for jatropha and $20 \%$ of respondents claiming indirect deforestation from the relocation of displaced food crops, an estimated $44 \%$ of the area of feedstock expansion is estimated to have come at the expense of forests in the study site, and $71 \%$ if including both forest and fallow. While this appears to be roughly on par with the industrial-scale jatropha plantation in Ghana, biofuel-induced deforestation in the Zambia case is actually far less considering that the calculations for Ghana include only direct land-use change.

\section{Implications of land-use change for the climate mitigation} potential of biofuels

The implications of land-use change for the climate mitigation potential of biofuels in the case study sites were assessed through evaluations of carbon debts associated with land-use change and the proportion of this debt attributable to the biofuel (and other products), life cycle $\mathrm{CO}_{2}$ emission reduction rates from substituting fossil fuels with the biofuel, and carbon debt repayment times (Achten and Verchot 2011). Oil palm was found to create the largest carbon debts per unit area because of both the high carbon content in the above- and 
belowground biomass of forests that were cleared and the high proportion of forests that were lost to plantation expansion. Carbon debts from direct and total (direct + indirect) land-use change for these systems were in the range of 254-1579 tonne/ ha $\mathrm{CO}_{2}$ equivalent (eq.) and 266-1744 tonne/ha $\mathrm{CO}_{2}$ eq., respectively, with the larger values derived from sites where carbon-rich peat swamp forest was converted (West Kalimantan, Indonesia). Although total carbon debts associated with jatropha and soybean were significantly lower, with ranges of 39-496 and 57-574 tonne/ha $\mathrm{CO}_{2}$ eq., respectively, carbon debts can reach levels similar to those for oil palm under scenarios of indirect land-use change of $\geq 50 \%$. The carbon debts for soybean rapidly diminish relative to the other two feedstocks when allocating carbon debts per unit area across end products and land uses, given the economic value of soybean meal and maize, the predominant intercrop. Although this method does little to reduce the real impact of soybean on forests, it does make it the feedstock with the lowest carbon debts attributable to the resulting biofuel.

Life cycle $\mathrm{CO}_{2}$ emission reduction rates associated with fossil fuel substitution show, not surprisingly, that oil palm systems have the highest $\mathrm{CO}_{2}$ emissions reduction rates, at eight to nine times those of soybean. Depending on yield, the $\mathrm{CO}_{2}$ emission reduction rates for jatropha may be higher or lower than for soybean. The carbon debt repayment times, calculated from these values and the carbon debt assessments for each feedstock and site, were lowest for soybean (18-41 yr, depending on the rate of indirect land-use change), followed by jatropha (46-70 yr for dry forest sites; potentially much higher for tropical Mesoamerican sites) and oil palm on mineral soils (34-85 yr), and finally oil palm on peatlands (206-220 yr). Most importantly, in the vast majority of cases (for all feedstocks), carbon debts postpone net greenhouse gas reductions from biofuels by more than one human generation, raising the question of whether it is justified for biofuels to carry their widely touted green label.

Only for jatropha can we explore the differential effects for smallholder and industrial-scale plantations. Although carbon debt calculations for smallholder systems in Mexico (Chiapas, Michoacan) rival or exceed those associated with the industrial-scale jatropha plantation in Ghana, these values should be interpreted with caution given the weight of uncertain land-use change scenarios in an ecoregion with high carbon stocks for primary forest. It does, however, illustrate the importance of forest type, yield, and feedstock on carbon debt accrual. A comparison of the carbon debts in the dry forests of Ghana and Yucatan with those from Zambia, where smallholder land-use decisions and related direct and indirect land-use change were assessed, would suggest that carbon debts are several times higher in industrial-scale plantations. These values, strongly influenced by location-specific landuse changes that occur as biofuels expand, can be expected to vary considerably based on local ecological conditions, demographics, land-use competition, and the strength of environmental legislation, and should not be interpreted as a wider reflection on the inherent characteristics of different business models. Findings for $\mathrm{CO}_{2}$ emission reduction rates, which were higher for the industrial-scale system (Ghana), can be considered more representative than the carbon debts, given the widespread tendency for higher yields to characterize these high-input systems. These opposing trends resulted in carbon payback ranges that are not significantly different between these two systems. However, the significant effects of direct and indirect land-use change and yield on the resulting carbon debts point to the fundamental importance of high-quality support services to smallholders and environmental controls on large-scale operators in avoiding a situation in which biofuels perpetrate the very climatic challenges they were put forward to address.

\section{Socioeconomic impacts}

While environmental motives are the more prominent factor shaping consumer country policies and thus the upsurge in global biofuel demand, policy makers in the global South have systematically placed poverty alleviation, rural development, and employment creation, in addition to energy security, as key objectives behind policies to stimulate the biofuels sector. The degraded land narrative employed to minimize the social costs of biofuels in addition to their ecological cost must be scrutinized based on the cultural, economic, and food security functions of displaced land uses. This narrative is most prominent in dry forests of Ghana, Mexico, and Zambia, but has also been used to scapegoat shifting agriculturalists in Indonesia, who are blamed for the regional haze resulting from the burning of forests for the expansion of officially sanctioned industrial-scale plantations (German 2010). Because the expansion of biofuel feedstock cultivation tends to have a highly differentiated effect on local households, we examine the evidence from the perspective of key stakeholder groups who interface in different ways with the emerging biofuel industry.

\section{Customary land users}

\section{Processes of land acquisition}

Based on case study findings, the most profound negative impacts of biofuel feedstock expansion were associated with the displacement of customary livelihoods resulting from large-scale land transfer to investors. Economic losses stem both from the loss of agricultural and forest income and from the failure to channel benefits effectively to affected households. One of the key underlying causes is observed deficiencies in the process by which investors acquire land that is under customary use and ownership. We therefore review the evidence on practices employed in negotiating land transfer from customary land users to investors and the resulting effects on customary land users' livelihoods. 
Processes of large-scale land transfer vary considerably across the case studies. Land transactions in Brazil and Mexico, which usually involve voluntary transactions between land sellers and buyers, must be contrasted with land acquisition processes in countries where customary land rights are largely informal and thus insufficiently recognized by the state and private investors. In the industrial-scale plantation model observed in the Yucatan, jatropha is being grown by companies on large private ranches previously used by absentee landlords for low-intensity and low-profit grazing, and therefore is not resulting in smallholder displacement (Skutsch et al. 2011). In Brazil, the establishment of largescale soybean farms is largely occurring through voluntary market transactions. In some cases, this has led to the consolidation of landholdings by large agri-businesses through the displacement of less productive cattle ranching, often into the forest frontier. Additionally, processes of land concentration have been observed within agrarian reform settlements where soybean production has expanded; yet this has for the most part occurred within the context of voluntary land alienation by smallholders (Lima et al. 2011).

In the other case study countries, processes of large-scale land transfer were subject to a number of problems because of greater informality in the land sector, deficiencies in the law, and irregularities in practice. In each of the case study countries, there are mechanisms in the law both to recognize customary land rights and to award large concessions to private investors. In Ghana and Zambia, for example, chiefs who manage land on behalf of customary rights holders and other land users have the right to concede to or decline large-scale land leases (Ghana) or permanent transfer of ownership (Zambia) (German et al. 2011b, Schoneveld et al. 2011). Because chiefs can negotiate directly the terms of alienation, customary land users should in theory be able to secure annual or one-off payments for land transferred to investors. While untitled customary land is also recognized in Indonesian law, and compensation should be provided accordingly, land acquisitions only require consent when protected by a formal title. However, in Malaysia, where customary land rights are only recognized through formal title, there are no legal grounds to demand consent and compensation for the many households who have not undergone the lengthy and expensive land titling process (Dayang Norwana et al. in press).

Nevertheless, the highly uneven playing field of knowledge, need, and power during land negotiations observed in several cases exposed customary land users and authorities to manipulation by outside actors. This was observed in terms of agreements that were formulated in advance of community consultations or never committed to paper, the highly variable compensation agreements reached with different villages in a single concession area, limited awareness of the law among customary rights holders (e.g., whether agreements are temporary or permanent or require compensation), and the ease with which customary leaders were swayed by promises of development (Schoneveld et al. 2011, Obidzinski et al. unpublished manuscript). Furthermore, with significant alienation rights vested in the customary leadership, there is significant risk of elite capture, as evidenced by deals that were undisclosed or negotiated based on personal interest (Schoneveld et al. 2011, Obidzinski et al. unpublished manuscript). In Ghana, details of the agreements between chiefs and investors were never disclosed to local land users, and in the two sites in Papua, Indonesia, local conflicts ensued over the distribution of land payments given to tribal chiefs (Schoneveld et al. 2011, Obidzinski et al. unpublished manuscript). In most sites, customary land users were neither consulted nor informed prior to agreements being closed nor, in some cases, before land clearing was initiated. In Malaysia, for example, there was no community consultation, with only $23 \%$ of the respondents indicating that their families were formally notified about land transfer through a letter from the village head (Dayang Norwana et al. in press).

As for the terms of final agreements, most involved some form of compensation. In Ghana, agreements involving the payment of annual land rents and profit-sharing agreements with affected communities were both observed in exchange for 25or 50-yr renewable leases. In the case study site, the company reportedly made a verbal promise to draw at least $75 \%$ of the plantation workforce from the traditional area. In Indonesia, where 35-yr land leases are the norm, levels of compensation and their form (cash payment for land, displaced forest products, or labor; participation in a plasma scheme) were highly variable (Table 2; Obidzinski et al. unpublished manuscript). The variability in compensation, poor governance of payments, and delivery of goods and services of inferior quality has created conflict and dissatisfaction. This has led some customary leaders to push for additional compensation or to request their land back following the expiry of the initial lease. In Malaysia, no forms of compensation were identified.

\section{Impacts on customary land users}

The impacts on customary land users are shaped significantly by the extent to which they were displaced and the nature of benefit flows to affected households following land transfer. In the Southeast Asia study sites, decreased forest cover has resulted in greater difficulty in accessing forest products and practicing shifting agriculture, as well as the loss of income from forest-based industries such as logging. Households have either abandoned these activities altogether or suffer an increased labor burden by walking longer distances to collect forest products or to open new fields for shifting cultivation. In Indonesia, all respondent groups reliant on forests had to shift to on-farm activities (for those who still had access to land) or to off-farm work and to purchase the forest products they once sourced for free. Where increased land speculation 
has increased the cost of land, many land-losing households have been unable to acquire replacement land, although it is difficult to determine the relative influence of plantation establishment and wider processes of agrarian change (Obidzinski et al. unpublished manuscript). Livelihood declines were more significant where more traditional land uses prevailed, but benefits were greater where a significant number of households had prior experience with oil palm. In the Malaysian site, all land has now been converted to oil palm except for areas set aside as forest reserves, which has led to widespread abandonment of forest-based livelihoods. As many customary land users no longer own land, they are more dependent on hunting, gathering, and fishing than before, making deforestation and water pollution from mill effluent more keenly felt by this group. The reduced fish catch and inability to continue planting rice has resulted in the need to purchase much of the food consumed in the household, undermining household food security for many (Dayang Norwana et al. in press).

Table 2. Select cases of compensation payments to customary leaders in Papua, Indonesia.

\begin{tabular}{lcc}
\hline \hline Site & $\begin{array}{c}\text { Area of select land } \\
\text { deals (ha) }\end{array}$ & Compensation (US\$) \\
\hline $\begin{array}{l}\text { Manokwari, } \\
\text { Papua }\end{array}$ & 14,800 & $\$ 300,000$ \\
& 5,500 & $\$ 0$ \\
Boven Digoel, & 14,000 & $\$ 100,000$ \\
Papua & 8,000 & $\begin{array}{c}\text { Compensation for sago }(\$ 0.5 / \text { tree }) \\
\text { and timber }\left(\$ 1 / \mathrm{m}^{3}\right) \text { only } \dagger\end{array}$ \\
& & \\
$\begin{array}{l}\dagger \text { It is unclear how much was actually paid in compensation. The } \\
\text { equivalent value, based on yield estimates, was in the order of }\end{array}$ \\
$\begin{array}{l}\text { US\$300,000 for timber and sago alone (Obidzinski et al. unpublished } \\
\text { manuscript). }\end{array}$
\end{tabular}

In Ghana, the average household lost more than three-quarters of its landholdings by the end of 2009. With few households able to acquire replacement land, and replacement land constituting only a fraction of initial landholdings, agricultural incomes are severely compromised (Schoneveld et al. 2011). Furthermore, half of the households that successfully acquired replacement land found it to be of lesser quality and much further from their homes than the land lost to the plantation. Most respondents reported declining contributions of forestry and agricultural activities to household livelihood portfolios (98 and $73 \%$ of respondents, respectively), and overall declines in the standard of living $(73 \%)$, with some households abandoning these activities altogether. Significant loss of women's income streams were observed through the destruction of minor crops during plantation establishment and marked declines in the availability of high-value forest products. This case illustrates the significance of livelihood costs and potential risks to food security, even in landscapes with low population densities. Notably, in no site were negative impacts from the displacement of customary land uses considered to be significant where biofuel feedstock expansion occurred through smallholder-based production rather than industrial-scale plantations, as the land-use decisions remain voluntary.

Considering that the long-term effects on customary land users will depend a great deal on the extent to which they are able to capture opportunities associated with biofuel feedstock expansion, it is important to explore the extent to which affected households either benefit from the preferential policies of biofuel companies or are able to capture proactively other opportunities brought by the industry. Although employment generation could in theory be a key avenue for livelihood reconstruction, access to employment among customary land users was found in several cases to be constrained by the preference shown by companies toward outside hiring. In Ghana, for example, only $4 \%$ of land-losing households had secured employment at the time of research despite their expressed interest in formal employment and the company's promise to provide preferential employment to households in the traditional area (Schoneveld et al. 2011). In Indonesia and Malaysia, the majority of jobs on plantations went to migrants from outside the affected communities, other provinces, or (as in the case of Sabah) other countries. In Indonesia, the skill base and work ethic of local residents are often considered inadequate by managers, and most of the local residents were unable to secure or retain jobs on plantations (Obidzinski et al. unpublished manuscript). The poor employment conditions for unskilled laborers further undermine these benefits in some cases. And while corporate social responsibility practices and economic spillovers brought concrete benefits to local residents in the Indonesian and Malaysian cases, services provided by companies are often restricted to employees in the former case, contrary to the original expectations of recipient communities. In Malaysia, where many residents have resisted plantation employment because of poor employment conditions and competition with traditional livelihood activities, the industry attracts mostly employees from poor and remote areas and neighboring Indonesia (Dayang Norwana et al. in press).

Important differences were observed in the distribution of benefits between long-time residents and recent migrants. In Indonesia, migrant households fare better than local residents. In addition to capturing more of the employment benefits, they do not experience the negative effects associated with land loss because of their lesser dependence on forests or receipt of formal land titles through government-financed transmigration schemes (Obidzinski et al. unpublished manuscript). In Ghana, on the other hand, migrant households were far less likely to receive replacement land than native inhabitants, and the replacement land acquired by these households was three times smaller on average (Schoneveld et al. 2011). 


\section{Employees}

To explore whether the biofuel sector is in fact delivering on stated aims of stimulating rural development through employment generation, it is important to look at both job creation and job quality. To assess the extent to which employment in biofuel plantations has resulted in net benefits, it is also important to understand the benefits of employment relative to the activities displaced by industrial-scale plantations or relative to other employment options.

Although the level of employment among customary land users and households losing land to plantations is low, in most of the case studies, concrete livelihood benefits were observed from employment. In Brazil, where the industry is most advanced, the quality of employment, particularly in relation to wages, is high (Lima et al. 2011). In Malaysia, where free housing, potable water, electricity, medical services, schooling for children, and sports facilities are provided to all employees, $77 \%$ of respondents felt that employment had improved their incomes and livelihood conditions (Dayang Norwana et al. in press). In Ghana, $67 \%$ of respondents considered plantation employment to have had a net positive impact on their livelihoods because of steady income flows, despite very recent employment (Schoneveld et al. 2011). Employees in Indonesia and Mexico also cited regular income flows as a key benefit over agriculturally based livelihoods. In Mexico as well, where jatropha cultivation has reportedly driven up local wage rates, employees hired by small-scale feedstock growers rated their livelihood gains more highly than did any other group (Skutsch et al. 2011). In Indonesia, findings were more mixed, with employees in one site overwhelmingly reporting positive net livelihood impacts, and nearly half of respondents in a site in Papua perceiving negative impacts (Obidzinski et al. unpublished manuscript). This difference may be attributed to cultural factors such as a group's prior experience with wage labor, and to poor working conditions in the latter case, including the casual nature of employment and the long working hours that resulted from the company's performance-based pay system. Indigenous Papuans forced to abandon traditional livelihood activities and seek wage-based employment have faced difficulties adapting; this observation was also made in relation to indigenous communities in the Malaysian case.

Although the perceived household-level livelihood impact of employment is an important metric for appraising the local impact of employment generation, impacts should also be appraised in the context of opportunity costs in the aggregate (e.g., the total value of employment relative to displaced land uses). In the Brazilian cerrado, for example, employment levels on soybean estates are very low because of the high degree of mechanization, with a typical farm employing as few as 1 full-time (skilled) and 1.5 temporary (unskilled) workers/500 ha. Yet with ranching employing fewer people per unit area than soybean cultivation, the associated returns to land may still improve under biofuel feedstock cultivation (Lima et al. 2011). In Ghana, on the other hand, greater returns to land were found from displaced land uses than from formal employment (Schoneveld et al. 2011). With employment levels at around one employee/7 ha of plantation area, the most important former cash crop alone (yam) was found to outcompete jatropha, generating $110 \%$ of the per-unit-area value of employment. Employment would compare far less favorably if the value of other displaced land uses (minor crops, charcoal, high-value non-timber forest products, hunting) were considered. Thus, although the employment generated by biofuel feedstock expansion is generally viewed positively by beneficiary households, with countries giving away nationally significant tracts of land in the name of employment generation, it is critical that the returns to land and labor from plantation employment be subject to scrutiny.

\section{Small-scale growers}

We now examine the extent to which the biofuel industry has enhanced rural incomes through smallholder participation in biofuel feedstock production in the research sites, which is a stated policy aim in most case study countries. In countries where smallholders were engaged in feedstock production in well-established biofuel feedstock industries (Brazil, Indonesia, Malaysia), concrete benefits were observed. In Malaysia and Indonesia, livelihood improvements to smallscale growers were associated with increased income, more flexible working hours, and improvements in infrastructure (Dayang Norwana et al. in press, Obidzinski et al. unpublished manuscript). In Brazil, farmers producing feedstock for sale to soybean processing companies under the Social Fuel Seal program have also benefited from a policy that provides biodiesel producers incentives to source their raw materials from smallholders and family farms (defined as farms $<100$ ha in size; Lima et al. 2011).

However, in each of these countries with more established biofuel industries, there was evidence to suggest that the wealthier operators are better able to capture the benefits of the emerging biofuel industry. In Brazil, despite the government policy explicitly supporting family farms, the high cost of providing technical support to smaller operators means that settlements in which individual landholdings are much less than 100 ha are largely overlooked by companies. Moreover, barriers to market entry, including high transport costs, restricted access to credit (for which land titles are required), and the need for certificates showing that no deforestation has occurred, have limited smallholder participation in soybean cultivation (Lima et al. 2011). Processes of consolidation in the sector have also increased the competitive barriers faced by Brazilian smallholders. In Indonesia, smallholders in West Kalimantan were able to leverage the greatest benefits because they had more capital 
to invest and were able to establish more beneficial partnerships with industry (Obidzinski et al. unpublished manuscript).

In cases where smallholders are engaged in feedstock production in emerging biofuel industries (Mexico, Zambia), meaningful benefits have yet to materialize. Findings suggest very low profit margins and returns to labor for jatropha farmers, even in the case of Mexico, where plantation establishment costs are subsidized by the government (Skutsch et al. 2011). In Zambia, the company apparently abandoned farmers entirely, delivering only seed and technical support out of many promised benefits, and never returned to procure their produce. Nongovernmental organizationsupported efforts to provide an alternative market to farmers, although too new to evaluate, had provided some returns, though with costs greater than benefits when factoring in labor (German et al. 2011a). In both sites, incentives (i.e., government subsidies in Mexico, and unfulfilled company promises of loans and annual payments until harvest in Zambia) were found to be a key factor motivating farmers to invest in jatropha. It therefore remains to be seen whether farmers will find jatropha cultivation a worthwhile economic pursuit as the industry matures, considering, in particular, low observed yields and limited market outlets. Household wealth also seemed to shape a family's ability to invest, with jatropha farmers having larger than average landholdings or greater than average wealth.

Considering the limited benefits that have accrued to date, small-scale jatropha farmers are bearing much of the risk associated with an emerging and largely untested jatropha industry. This was found to be exacerbated by extended contracts (up to 30 years in Zambia), the absence of counterclauses requiring the company to purchase seed, the failure to contractualize pricing mechanisms, the lack of any legal basis for company commitments, and the inability of companies to uphold their commitments due to cash flow problems (German et al. 2011 $a$, Skutsch et al. 2011). Farmer responses have been mixed, with some farmers in both countries pulling up or neglecting their plantations and others continuing to invest with the hope of future returns. The financial instability of jatropha outgrower companies and of the market, as well as the nature of contractual agreements, thus poses a risk to smallholders who may experience negligible returns on investment.

Given government and civil society concerns over the displacement of food crops, it is important to reflect on evidence for crop displacement associated with smallholderbased feedstock production within the case study sites. Findings suggest that it is common practice for smallholders to displace food crops from permanent fields or shifting agricultural plots to cultivate biofuel feedstocks, a pattern which is common for newly introduced cash crops. In Mexico, some households were even cultivating jatropha on prime irrigated land (Skutsch et al. 2011). In Zambia, where food security effects were analyzed in greater detail, the vast majority of households were observed to be integrating jatropha into permanent agricultural plots and/or using land that formed part of the shifting agriculture system (German et al. 2011a). Despite these changes, because of the practice of intercropping jatropha with existing food crops, only $39 \%$ of respondents indicated that food crops were displaced. When this did occur, the displaced crops were typically reestablished elsewhere, some on more fertile plots, suggesting that jatropha can be integrated into existing farming systems comparatively well when ample land remains available. Despite these promising findings, efforts to disaggregate these data illustrated that these averages hide inter-household variability in food security impacts, with some households experiencing drops in food production because of land-use changes or labor shortages (German et al. 2011a). In Malaysia, almost all respondents completely abandoned food crop production in favor of oil palm cultivation (Dayang Norwana et al. in press). Although households are no longer food selfsufficient, food security was reportedly not undermined by this shift, yet government subsidies were required to maintain rural livelihood security in the face of fluctuating world market prices. In Indonesia, the majority of respondents reported increased access to food.

\section{IMPLICATIONS FOR SECTOR GOVERNANCE}

\section{Governing environmental impacts: feasibility of environmental controls}

Current governance instruments to regulate the environmental impacts of biofuel feedstock cultivation include national environmental impact assessment legislation, sustainability criteria employed by major consumers countries (e.g., the European Commission's Renewable Energy Directive), and voluntary standards adopted by industry (e.g., Roundtable on Sustainable Palm Oil, Roundtable on Responsible Soy). Common origins, ISO standardization of environmental impact assessment (EIA) scope and steps (Standard 14011), adoption of environmental impact standards by Organisation for Economic Cooperation and Development member states (Japan Ministry of the Environment 2011), and efforts by donor agencies to make environmental impact assessments a condition of lending and to build related capacities in developing countries have led to relatively standardized environmental impact assessment procedures and legislation in the case study countries (Sadler 1996, Caroko et al. 2011, Chin 2011, Schoneveld and German 2010, German and Schoneveld in press). Most of the biofuel producers in the Southeast Asian and African case study countries are targeting the European market, where a sustainability scheme has been introduced to certify biofuels that are used to fulfill member states' renewable energy commitments. Furthermore, the 
investors studied in West Kalimantan, Indonesia, and in Sabah, Malaysia, are subsidiaries of the Roundtable on Sustainable Palm Oil-certified company Wilmar International Limited (Committed to certification: http://www.wilmar-inte rnational.com/sustainability/certification.htm).

The significance of environmental impacts documented in the case studies in this special issue illustrates the limitations in these instruments for mitigating deforestation and its associated effects such as greenhouse gas emissions, biodiversity, and hydrological effects. As for national EIA procedures, although design limitations do exist (e.g., indicators that do not adequately target avoided deforestation), the real limitations seem to be in the deficiencies of capacity and political commitment to monitor and enforce. This must be juxtaposed with the economic development imperative and ambitious expansion targets for biofuels and related agroindustries, which often explicitly target carbon-rich and biodiverse forests and woodlands in a bid to minimize food security impacts, among other reasons (Colchester et al. 2006, Obidzinski et al. unpublished manuscript). These targets and the economic and political interests bolstering them, together with negative stereotypes about the shifting agricultural practices which predominate in these areas, will make this situation difficult to reverse in the near future. While efforts are clearly needed to bolster the adherence of private operators to voluntary sustainability standards and to strengthen domestic legislation that such standards often refer to, the findings suggest that these may, in many cases, be insufficient because of the incomplete scope of standards or incomplete coverage of operators within supply chains. Sustainability standards in the EU (Directive 2009/28/EC) and related commitments to global climate change mitigation offer perhaps the best opportunities to regulate environmental impacts of biofuel feedstock expansion. The effectiveness of such schemes is, however, limited by the proportion of feedstock destined to the energy market and by the extent to which other key buyers make similar policy commitments. These governance challenges suggest that additional efforts will be needed to analyze and modify the set of economic incentives currently facing commercial operators in their decisions to target forest-rich landscapes for biofuel feedstock expansion.

Brazil seems to be a notable exception to the trend of ineffective environmental controls; its deforestation rates have been reduced as a result of a combination of national regulatory, industry and civil society-led initiatives (Nepstad et al. 2009). Among these is the Soy Moratorium, signed by almost all of the major buyers, which prohibits purchases of soybean from landholdings that disobey environmental legislation such as forest conversion permits. Other factors decreasing cropland expansion into the forest frontier include increasing transparency in the monitoring of deforestation, greater involvement of prosecutors in enforcing land-use regulations, and the role of finance conditionalities in enhancing compliance with national legislation (May et al. 2011). The factors underlying Brazil's relative success need to be looked at more closely as a means of understanding the extent to which it is replicable in other contexts.

\section{Protecting the rights of customary land users}

The case studies in this issue illustrate the challenges associated with protecting customary land rights in the context of large-scale land acquisitions for biofuel feedstock production. A fundamental first step, taken to different degrees in the case study countries and elsewhere, is to legislate the protection of customary land rights. Attention should be given both to the scope of legal protections for customary land users and to procedures for having these protections recognized. In terms of scope, protections that extend beyond customary leaders to all affected households; legislating free, prior, and informed consent as a procedure through which land rights are acquired from customary land users; and mandated compensation of land, land investments, and other natural resources are sorely needed (Colchester 2011, Cotula 2011, German et al. 2011b). Procedural needs include the simplification of registration procedures to minimize the barriers faced by poorer households in securing their rights and the recognition of customary rights without formal registration (Republic of Mozambique 1997, Cotula 2011). It is important to recognize, however, that policy and legislative reforms that simultaneously strengthen customary land rights and the ability of (foreign) investors to secure access to vast areas of land for extensive periods often create only the illusion of equity because of deep asymmetries in knowledge and power and in government policies incentivizing agroindustrial expansion. The benefits of strengthening national legal frameworks for customary rights protection may therefore result more from the benchmarks provided for market-based certification instruments, which generally include provisions for compliance with national laws, and for civil society, for monitoring legal compliance, than from anticipated legal protections by public agencies. However, this is not always the case. In Brazil, for example, the state exerts an active role in enforcing customary rights, mainly of indigenous people.

Given the observed disconnects between law and practice in the context of large-scale land acquisitions in sub-Saharan Africa and Southeast Asia (Colchester et al. 2006, Colchester 2011, German et al. 2011b, Schoneveld et al. 2011), additional steps are required to monitor actual practices and outcomes for customary land users. As the case studies in this special issue demonstrate, this is required for challenges to customary rights protections arising at multiple stages of the land acquisition process. These include: the promotional measures taken by government, including commitments to investors that cement economic development pathways and related land deals prior to local consultations; the highly uneven playing 
field of knowledge, need, and power during negotiations between investors and customary land users; and the poor internal governance of the negotiation process and benefits distribution within affected communities. These represent very real challenges that defy simple solutions. As these and other case studies show, conflicts of interest and political manipulation are rife in land policy-making and land negotiations, raising further challenges to procedural and distributional justice in the context of large-scale land negotiations (Sitoe 2009, Nhantumbo and Salomão 2010, Cotula 2011). Here, simple, unambiguous, and easily monitored rules are likely to be more meaningful in protecting the rights of customary land users than complex processes for social inclusion. Establishing lower caps on the duration of land leases and mechanisms for the land to return to customary users upon expiry of land leases will minimize some of the most significant risks to customary land users. Legislating caps on land area also seems to be merited by the slow pace at which investors have proven capable of implementing investment commitments and by the social cost of large, contiguous investments that isolate communities from traditional livelihood practices (Schoneveld et al. 2011, Dayang Norwana et al. in press, Obidzinski et al. unpublished manuscript).

There is also an urgent need to invest in enhancing the ability of affected households to claim and defend their rights (Cotula et al. 2008, Colchester 2011; E. Mwangi and H. Komarudin, personal communication). Bolstering legal literacy on land rights, on the importance of specificity in the terms of agreement, on the long-term consequences of land transfer, and on the conditions under which agreements are enforceable, including the fact that verbal commitments are as good as none, are paramount. Economic valuation of local assets and income-generating potential prior to negotiations, and simple methods for doing so, are also sorely needed to raise awareness on the value of assets that could be lost through land transfer and thus strengthen the negotiating position of affected households.

\section{Moving toward smallholder-inclusive business models}

Our synthesis of findings from the case study sites shows that smallholder-oriented business models, especially in wellestablished feedstock sectors, are likely to produce greater local benefits than commercial plantations. Given the increasing propensity in recent years for agri-business to engage directly in upstream activities (von Braun and Meinzen-Dick 2009, Deininger and Byerlee 2011), there is increasing risk for smallholder producers to be excluded from new opportunities in the global soft commodity markets. In addition, increasing control over markets by large agribusinesses has led to significant market restructuring, which has in turn favored the interests of medium- and large-scale producers. These larger operators are more able to compete in international markets than smallholders, who often lack capital to specialize in selected crops offering higher returns as well as knowledge of market opportunities.

Market failures such as economic or institutional barriers to market entry, limited access to inputs, and structural power asymmetries are often found to undermine smallholder participation. Economic theory therefore typically advocates government intervention to restore market functioning (Krueger 1990). However, historical experiences have shown that comprehensive government interventions of this sort are rarely technically and economically feasible over time, even for the comparatively successful Nucleus-Plasma schemes in Indonesia (Zen et al. 2005). For example, most of the integrated rural development policies that prevailed in the 1960s and 1970s were fiscally unsustainable as a result of excessive government spending on agricultural inputs, research and development, bureaucracy, and state-coordinated marketing (Ellis and Biggs 2001, Wiggins et al. 2010). Due to these inefficiencies, to ideological shifts, and to the conditions of structural adjustment programs of the 1980s, public spending on and interventions in the agricultural sector have decreased substantially in most developing countries (Fan and Saukar 2006). As a result of weak administrative and technical capacity in agricultural ministries, exacerbated in part by these structural adjustment reforms, many people question whether the costs are justified by the benefits of comprehensive state intervention in the market, especially in the supply of private goods (Cabral and Scoones 2006, Hazell et al. 2007).

This raises the question of what role public agencies should play in supporting smallholder-inclusive business models. Some authors consider direct market interference by the state to be warranted in pre- and post-harvest support for staple crop markets (Poulton et al. 2008). However, given the previously discussed constraints to smallholder market entry, simplified and targeted market-oriented regulations and initiatives that aim to enhance the vertical and horizontal integration of smallholders into cash crop markets are also likely to go a long way in enhancing smallholder participation. For example, mandating agri-business to fulfill smallholder supply quotas, under the right conditions, can be a highly effective, low-cost measure for scaling up smallholder participation (Vermeulen and Cotula 2010). However, as is illustrated by the Social Fuel Seal initiative in Brazil, parameters for defining what constitutes a smallholder (e.g., with landholdings small enough to be socially meaningful) are an important determinant of the social benefits that may be derived from such initiatives (Lima et al. 2011). Restrictions on the area of land that can be held by agri-business, as have recently been imposed on foreign companies in Brazil and on biofuel companies in Tanzania and are under negotiation in Argentina, could enhance the necessity of smallholder feedstock sourcing and enhance the bargaining power of the smallholder sector, under the right circumstances. 
As Kherallah et al. (2000) note, where the market systematically fails in developing countries is in the provision of inputs, particularly fertilizers; because of diminishing subsidies and price inflation in many countries, this has resulted in declining input application rates. Despite the risks associated with formalized company-smallholder relations, as highlighted previously, contract farming-type schemes are one of the key alternatives to public subsidies for enhancing smallholder access to and use of inputs (Glover and Kusterer 1990, Baumann 2000). These types of business models can be promoted through, for example, introducing differential fiscal incentives, such as preferential income tax rates or increasing deductibles, between plantation companies and companies engaged in contract farming. In the Zimbabwean cotton and tobacco sectors, for example, agribusinesses are legally obliged to enter into a standardized contract with smallholders on an annual basis and provide inputs on credit (Schoneveld and Gumbo 2010). With private and public sector actors and farmer representatives negotiating the terms of contract on an annual basis, the risk associated with power and information asymmetries is significantly reduced. A more bottom-up approach could involve efforts to enhance collective action through the promotion of farmer organizations, which could function as intermediaries between smallholders and the private sector to minimize transaction costs or enhance the voice of smallholders vis-à-vis government or industry (Goldsmith 1985, Baumann 2000). Such groups could also be used for channeling agricultural extension services in a more cost-effective manner and targeted by non-government organizations and other service providers for capacity building initiatives.

As the Zambian and Mexican case studies illustrate, some caution is warranted in the promotion of contract farming schemes. Both cases show how farmers may adopt a new crop not necessarily out of faith in its potential profitability, but to gain access to up-front incentives or inputs. Although these motives for participation might not necessarily be problematic, they might introduce inherent risks in cases where slow maturing crops for which agronomic experience is limited displace traditional land uses and fail to generate higher marginal returns. In this regard, it appears critical that the state regulate (e.g., through the conditions placed on the licensing of operators) the pace and scale of smallholder contracting until the agronomics, business models, and economics are demonstrated to be viable. It is also critical that smallholder expectations be managed through, for example, governmentsupported sensitization initiatives and/or research and development activities to determine the type of extension services and inputs smallholders require to achieve economically and environmentally viable feedstock cultivation.

\section{DISCUSSION AND CONCLUSIONS}

The ineffectiveness of environmental controls to halt deforestation and related impacts on biodiversity loss, the persistent insecurity of land and resource tenure for local people, and the limited ability of smallholders to benefit from opportunities of emerging markets are issues that are causally linked in the biofuel feedstock sector. Several policy and market failures currently hinder the ability of the biofuel sector and other emerging markets to generate durable, shared value for the rural poor and to contribute to models of local economic development that minimize negative environmental impacts. Common to these governance arenas are deficiencies in national policies and limited capacity of governments in producer countries to enforce rules related to land use and management. Another salient theme is the ability of more powerful actors to capture the lion's share of benefits afforded by policy incentives. While smallholders are leveraging significant benefits in well-established oil palm industries in Southeast Asia, market failures and asymmetries further constrain smallholders from benefiting from emerging industries. In combination, these factors pose a set of institutional challenges to a sustainable and equitable biofuel sector.

As suggested elsewhere (Ostrom 2005, Pacheco et al. 2011), neither states nor markets, in isolation, are sufficient. Complex combinations of regulatory and market-based instruments, operating at different scales, are needed to manage the impacts of investments in biofuel and multi-purpose feedstocks. This is particularly true given the web of actors involved in inducing these impacts, including individual producers or companies, trade corporations, the processing industry, and investment banks and financial institutions, and the diversity of strategies through which they seek to maximize profits (van Gelder and German 2010, Campanale 2011 as cited in High Level Panel of Experts 2011).

The role of governments in consumer countries is also critical, particularly in the introduction of regulations to constrain imports of unsustainably produced goods (German and Schoneveld 2011). While this is important from the demand side, it may lead to trade barriers that favor domestic production over imports or those actors with the financial capacity to comply, thereby excluding local actors who are unable to comply with related standards (van der Meer 2006). It is also only as effective as the underlying rules governing market access, as illustrated by the weak coverage of social sustainability concerns in the European Union's Renewable Energy Directive and the voluntary schemes approved for verifying compliance (German and Schoneveld 2011). Thus, coupling such instruments with regulations, incentives, and services in producer countries to enhance the vertical integration of smallholders into biofuel value chains and to safeguard the interests of producer countries will enhance the potential for reconciling environmental and social aims and 
outcomes. Furthermore, to enhance their effectiveness, conditions imposed by consumer countries must be linked to verification processes that are reliable and transparent. These attempts need to synergize with national regulatory efforts related to land and forest resource use and customary rights protections, with a focus on the landscapes that are under the highest pressure of commercial agricultural expansion or where land use and ownership are contested. Aligning consumer and producer country initiatives can also be critical in reducing the risk of leakage of negative effects associated with the relocation of large-scale investments to territories with weaker governance and a resulting "race to the bottom" in sector governance.

Effective enforcement of national environmental regulations will tend to undermine land uses that are expanding at the expense of forests, yet generating income or revenue streams for local producers, trade corporations, and national and foreign investors. In this context, compliance with environmental regulations is unlikely unless there is a strong political will and capacity to enforce or conservation mechanisms to compensate for foregone benefits. In the absence of compensation, stronger environmental regulations and enforcement must be accompanied by support to land-use intensification. To achieve this, producer country governments and industry will face the challenge of providing better opportunities for smallholders to enhance the returns from agriculture and thus enhance production efficiencies. This can be done through the provision of public infrastructure or more effective extension services, or by enhancing smallholder access to improved seeds, fertilizers, and credit through contract farming or outgrower schemes. Such efforts are likely to result in positive effects for smallholders where they are sufficiently organized to strengthen their market position by creating economies of scale in transportation and marketing, for example. Thus, mobilizing the latent potential of local actors will also help to resolve market failures.

Foreign investors, including banks, institutional investors, governments, and entrepreneurs, who finance biofuel development in forest-rich countries of Africa and Southeast Asia, and domestic governments and banks who finance developments in Latin America and Southeast Asia, also have a fundamental role to play in applying social and environmental safeguards to their investments (van Gelder and German 2011). This potential is currently hindered by the limited number of private financiers and governments applying responsible investment instruments, by the poor coverage of the various types of finance they provide, and by the quality of safeguards employed (van Gelder and German 2011). There is therefore considerable scope for improving the adoption of responsible investment policies in the financial sector, particularly by government and commercial banks with an active role in supporting corporations investing in biofuel feedstock cultivation and processing in developing countries.
Furthermore, cases in which such safeguards are applied by plantation operators or outgrower companies to the operations from which they in turn source feedstock are rare or nonexistent. Innovative contractual agreements are therefore needed to promote more sustainable production practices along the entire value chain.

Governance challenges go beyond the governance of social and environmental impacts. Most of the production models observed in these case studies, whether industrial-scale plantations or outgrower schemes, lock land and labor into relatively inflexible arrangements that hinder the potential to adapt to changing socioeconomic and market conditions. Increased attention should be given to business models that are capable of enhancing resilience and adaptive capacity in the face of dynamic household realities and external environments and that are premised on the retention of choice for producer countries and local land users.

\section{RESPONSES TO THIS ARTICLE}

Responses to this article are invited. If accepted for publication, your response will be hyperlinked to the article. To submit a response, follow this link. To read responses already accepted, follow this link.

\section{ACKNOWLEDGMENTS}

This paper was produced with the financial assistance of the European Union under a project entitled, Bioenergy, sustainability, and trade-offs: Can we avoid deforestation while promoting bioenergy? The project's objective is to contribute to sustainable bioenergy development that benefits local people in developing countries, minimizes negative impacts on local environments and rural livelihoods, and contributes to global climate change mitigation. The project is managed by the Center for International Forestry Research and implemented in collaboration with the Council on Scientific and Industrial Research (South Africa), Joanneum Research (Austria), the Universidad Autónoma de México, and the Stockholm Environment Institute. The views expressed herein can in no way be taken to reflect the official opinion of the European Union. We thank the authors of the contributing papers in this special issue, whose work made this synthesis possible, and the reviewers who provided comments on an earlier draft.

\section{LITERATURE CITED}

Achten, W. M. J., and L. V. Verchot. 2011. Implications of biodiesel-induced land-use changes for $\mathrm{CO}_{2}$ emissions: case studies in tropical America, Africa, and Southeast Asia. Ecology and Society 16(4): 14. http://dx.doi.org/10.5751/ES04403-160414.

Andrade, R. M. T., and A. Miccolis. 2011. Policies and institutional and legal frameworks in the expansion of Brazilian biofuels. CIFOR Working Paper 71. Center for 
International Forestry Research, Bogor, Indonesia. [online] URL: http://www.cifor.org/publications/pdf files/WPapers/ WP71CIFOR.pdf.

Baumann, P. 2000. Equity and efficiency in contract farming schemes: the experience of agricultural tree crops. Working Paper 139. Overseas Development Institute, London, UK. [online] URL: http://www.odi.org.uk/resources/download/2022. pdf.

Cabral, L., and I. Scoones. 2006. Narratives of agricultural policy in Africa: What role for ministries of agriculture? Institute of Development Studies, University of Sussex, Brighton, UK. [online] URL: http://www.future-agricultures. org/pdf\%20files/MoA paper.pdf.

Caroko, W., H. Komarudin, K. Obidzinski, and P. Gunarso. 2011. Policy and institutional frameworks for the development of palm oil-based biodiesel in Indonesia. CIFOR Working Paper 62. Center for International Forestry Research, Bogor, Indonesia. [online] URL: http://www.cifor.org/publications/p df files/WPapers/WP62Komarudin.pdf.

Casson, A. 1999. The hesitant boom: Indonesia's oil palm subsector in an era of economic crisis and political change. Center for International Forestry Research, Bogor, Indonesia.

Chin, M. 2011. Biofuels in Malaysia: an analysis of the legal and institutional framework. CIFOR Working Paper 64. Center for International Forestry Research, Bogor, Indonesia. [online] URL: http://www.cifor.org/publications/pdf files/WPapers/ WP64CIFOR.pdf.

Colchester, M. 2011. Palmoil and indigenous peoples in South East Asia. International Land Coalition, Rome, Italy. [online] URL: http://www.landcoalition.org/sites/default/files/publication/912/ FPP_Malaysia_Indonesia_web_11.03.11.pdf.

Colchester, M., N. Jiwan, Andiko, M. Sirait, A. Y. Firdaus, A. Surambo, and H. Pane. 2006. Promised land. Palm oil and land acquisition in Indonesia: implications for local communities and indigenous peoples. Forest Peoples Programme, Sawit Watch, HuMA and ICRAF, Bogor, Indonesia. [online] URL: http://www.forestpeoples.org/sites/ fpp/files/publication/2010/08/promisedlandeng.pdf.

Cotula, L. 2011. The outlook on farmland acquisitions. International Land Coalition, Rome, Italy. [online] URL: htt p://www.landcoalition.org/sites/default/files/publication/899/ IIED_fatmland_web_11.03.11.pdf.

Cotula, L., N. Dyer, and S. Vermeulen. 2008. Fuelling exclusion? The biofuels boom and poor people's access to land. International Institute for Environment and Development, London, UK.

Dayang Norwana, A. A. B., R. Kunjappan, M. Chin, G. Schoneveld, L. Potter, and R. Andriani. In press. The local impacts of oil palm in Sabah, Malaysia: lessons for an incipient biofuel sector. CIFOR Working Paper 78. Center for International Forestry Research, Bogor, Indonesia.

de Andrade, R. M. T., and A. Miccolis. 2011. Policies and institutional and legal frameworks in the expansion of Brazilian biofuels. CIFOR Working Paper 71. Center for International Forestry Research, Bogor, Indonesia. [online] URL: http://www.cifor.org/publications/pdf files/WPapers/ WP71CIFOR.pdf.

Deininger, K., and D. Byerlee. 2011. Rising global interest in farmland: Can it yield sustainable and equitable benefits? World Bank, Washington, D.C., USA.

Dove, M. R. 1983. Theories of swidden agriculture, and the political economy of ignorance. Agroforestry Systems 1 (2):85-99. http://dx.doi.org/10.1007/BF00596351

Dove, M. R. 1993. A revisionist view of tropical deforestation and development. Environmental Conservation 20(1):17-24. http://dx.doi.org/10.1017/S0376892900037188

Ellis, F., and S. Biggs. 2001. Evolving themes in rural development 1950s-2000s. Development Policy Review 19 (4):437-448. http://dx.doi.org/10.1111/1467-7679.00143

European Commission. 2009. Directive 2009/28/EC of the European Parliament and of the Council. European Commission, Brussels, Belgium. http://dx.doi.org/10.1007/B F02176284

Fairhead, J., and M. Leach. 1996. Misreading the African landscape. Cambridge University Press, Cambridge, UK.

Fan, S., and A. Saukar. 2006. Public spending in development countries: trends, determination and impact. International Food Policy Research Institute, Washington, D.C., USA.

German, L. 2010. Local knowledge and scientific perceptions: questions of validity in environmental knowledge. Pages 99-125 in L. German, J. J. Ramisch, and R. Verma, editors. Beyond the biophysical: knowledge, culture, and power in agriculture and natural resource management. Springer, Dordrecht, The Netherlands. http://dx.doi.org/10.1007/978-9 0-481-8826-0 5

German, L., and G. Schoneveld. 2011. Social sustainability of EU-approved voluntary schemes for biofuels: implications for rural livelihoods. CIFOR Working Paper 75. Center for International Forestry Research, Bogor, Indonesia. [online] URL: http://www.cifor.org/publications/pdf files/WPapers/ WP75German.pdf.

German, L., and G. Schoneveld. In press. Review of the early legal and institutional framework for biofuel investments in Zambia. Review of Policy Research. 
German, L., G. C. Schoneveld, and D. Gumbo. 2011. The local social and environmental impacts of smallholder-based biofuel investments in Zambia. Ecology and Society 16(4): 12. http://dx.doi.org/10.5751/ES-04280-160412

German, L., G. Schoneveld, and E. Mwangi. 2011. Processes of large-scale land acquisition by investors: case studies from sub-Saharan Africa. Paper presented at the International Conference on Global Land Grabbing (Brighton, UK, April 6-8, 2011). Future Agricultures Consortium, University of Sussex, Brighton, UK. [online] URL: http://www.future-agri cultures.org/index.php?option $=$ com docman\&task $=$ doc download\&gid=1268\&Itemid=971.

Glover, D., and K. Kusterer. 1990. Small farmers, big business: contract farming and rural development. Macmillan, London, UK.

Goldsmith, A. 1985. The private sector and rural development: Can agribusiness help the small farmer? World Development 13(10-11):1125-1138.

Hazell, P., C. Poulton, S. Wiggins, and A. Dorward. 2007. The future of small farms for poverty reduction and growth. 2020 Discussion Paper 42. International Food Policy Research Institute, Washington, D.C., USA.

High Level Panel of Experts. 2011. Land tenure and international investments in agriculture. A report by the High Level Panel of Experts on Food Security and Nutrition. Food and Agriculture Organization, Rome, Italy. [online] URL:

http://www.fao.org/fileadmin/user upload/hlpe/hlpe documents/ HLPE-Land-tenure-and-international-investments-in-agriculture-2011. pdf.

Holmes, D. A. 2002. Indonesia: Where have all the forests gone? World Bank, Washington, D.C., USA.

Japan Ministry of the Environment. 2011. History of EIA systems and measures taken around the world. Japan Ministry of the Environment, Tokyo, Japan. [online] URL: http://www. env.go.jp/earth/coop/coop/document/10-eiae/10-eiae-2.pdf.

Johnson, F. X., and F. Rosillo-Calle. 2007. Biomass, livelihoods and international trade: challenges and opportunities for the EU and southern Africa. Stockholm Environment Institute, Stockholm, Sweden.

Kherallah, M., C. Delgado, E. Gabre-Madhin, N. Minot, and M. Johnson. 2000. The road half traveled: agricultural market reform in sub-Saharan Africa. Food Policy Report 10. International Food Policy Research Institute, Washington, D. C., USA. [online] URL: http://pdf.usaid.gov/pdf_docs/PNAC R621.pdf.

Koh, L. P., and D. S. Wilcove. 2008. Is oil palm agriculture really destroying tropical biodiversity? Conservation Letters 1(2):60-64.
Krueger, A. 1990. Government failures in development. Journal of Economic Perspectives 4(3):9-23.

Kull, C. A. 2004. Isle offire: the political ecology of landscape burning in Madagascar. University of Chicago Press, Chicago, Illinois, USA.

Lapola, D. M., R. Schaldach, J. Alcamo, A. Bondeau, J. Koch, C. Koelking, and J. A. Priess. 2010. Indirect land-use changes can overcome carbon savings from biofuels in Brazil. Proceedings of the National Academy of Sciences 107 (8):3388-3393.

Lima, M., M. Skutsch, and G. de Medeiros Costa. 2011. Deforestation and the social impacts of soy for biodiesel: perspectives of farmers in the South Brazilian Amazon. Ecology and Society 16(4): 4. http://dx.doi.org/10.5751/ES-0 4366-160404

May, P. H., B. Millikan, and M. F. Gebara. 2011. The context of REDD+ in Brazil: drivers, agents and institutions. CIFOR Occasional Paper 55. Center for International Forestry Research, Bogor, Indonesia. [online] URL: http://www.cifor. org/publications/pdf_files/OccPapers/OP-55.pdf.

Nepstad, D., B. S. Soares-Filho, F. Merry, A. Lima, P. Moutinho, J. Carter, M. Bowman, A. Cattaneo, H. Rodrigues, S. Schwartzman, D. G. McGrath, C. M. Stickler, R. Lubowski, P. Piris-Cabezas, S. Rivero, A. Alencar, O. Almeida, and O. Stella. 2009. The end of deforestation in the Brazilian Amazon. Science 4(326):1350-1351.

Nhantumbo, I., and A. Salomão. 2010. Biofuels, land access and rural livelihoods in Mozambique. International Institute for Environment and Development, London, UK. [online] URL: http://pubs.iied.org/pubs/pdfs/12563IIED.pdf.

Ostrom, E. 2005. Understanding institutional diversity. Princeton University Press, Princeton, New Jersey, USA.

Pacheco, P., L. German, J. W. van Gelder, K. Weinberger, and M. R. Guariguata. 2011. Avoiding deforestation in the context of biofuel feedstock expansion: an analysis of the effectiveness of market-based instruments. CIFOR Working Paper 73. Center for International Forestry Research, Bogor, Indonesia. [online] URL: http://www.cifor.org/publications/pdf files/WPapers/ WP73Pacheco.pdf.

Pleven, R. J., M. O’Hare, A. D. Jones, M. S. Torn, and H. K. Gibbs. 2010. Greenhouse gas emissions from biofuels' indirect land use change are uncertain but may be much greater than previously estimated. Environmental Science and Technology 44(21):8015-8021.

Poulton, C., G. Tyler, P. Hazell, A. Dorward, J. Kydd, and M. Stockbridge. 2008. Commercial agriculture in Africa: lessons from success and failure. World Bank, Washington, D.C., USA. [online] URL: http://siteresources.worldbank.org/INTA 
FRICA/Resources/257994-1215457178567/CCAA Success failure. pdf.

Reijnders, L., and M. A. J. Huijbregts. 2008. Palm oil and the emission of carbon-based greenhouse gases. Journal of Cleaner Production 16(4):477-482. http://dx.doi.org/10.1016/ j.jclepro.2006.07.054

Republic of Mozambique. 1997. Lei de Terras. Republic of Mozambique, Maputo, Mozambique.

Romero-Hernández, O., O. Masera, S. Romero, and M. Grunstein. 2011. Legal and institutional frameworks at national and subnational levels for biofuel promotion in Mexico. CIFOR Working Paper 63. Center for International Forestry Research, Bogor, Indonesia. [online] URL: http://w ww.cifor.org/publications/pdf_files/WPapers/WP63CIFOR.pdf

Romijn, H. A. 2011. Land clearing and greenhouse gas emissions from jatropha biofuels on African miombo woodlands. Energy Policy 39(10):5751-5762. http://dx.doi.or g/10.1016/j.enpol.2010.07.041

Sadler, B. 1996. Environmental assessment in a changing world: evaluating practice to improve performance. Final Report of the International Study of the Effectiveness of Environmental Assessment. Canadian Environmental Assessment Agency and International Association for Impact Assessment, Ottawa, Canada.

Sawyer, D. 2008. Climate change, biofuels and eco-social impacts in the Brazilian Amazon and Cerrado. Philosophical Transactions of the Royal Society B 363(1498):1747-1752. http://dx.doi.org/10.1098/rstb.2007.0030

Schoneveld, G., and L. German. 2010. Large-scale land acquisitions for biofuels: analysis of the Ghanaian policy, legal, and institutional framework. Unpublished project report. Center for International Forestry Research, Bogor, Indonesia.

Schoneveld, G. C., L. A. German, and E. Nutakor. 2011. Landbased investments for rural development? A grounded analysis of the local impacts of biofuel feedstock plantations in Ghana. Ecology and Society 16(4): 10. http://dx.doi.org/10 .5751/ES-04424-160410

Schoneveld, G., and D. Gumbo. 2010. The sun rises in the East: the impact of Zimbabwe's new allegiance to China. Unpublished project report. Center for International Forestry Research, Bogor, Indonesia.

Searchinger, T., R. Heimlich, R. A. Houghton, F. Dong, A. Elobeid, J. Fabiosa, S. Tokgoz, D. Hayes, and T.-H. Yu. 2008. Use of U.S. croplands for biofuels increases greenhouse gases through emissions from land-use change. Science 319 (5867):1238-1240.
Sitoe, A. 2009. Governação florestal em Niassa: o caso de muembe, sanga, lago e cuamba. Associação Rural de Ajuda Mútua, Maputo, Mozambique.

Skutsch, M., E. de los Rios, S. Solis, E. Riegelhaupt, D. Hinojosa, S. Gerfert, Y. Gao, and O. Masera. 2011. Jatropha in Mexico: environmental and social impacts of an incipient biofuel program. Ecology and Society 16(4): 11. http://dx.doi. org/10.5751/ES-04448-160411

U.S. Congress. 2007. Energy independence and security act of 2007. U.S. Congress, Washington, D.C., USA. [online] URL: http://frwebgate.access.gpo.gov/cgi-bin/getdoc.cgi? dbname=110_cong_public_laws\&docid=f:publ140.110.pdf.

Valentino, S. 2011. Tanzania biofuel project's barren promise. IPS-Inter Press Service, Rome, Italy. [online] URL: http://ips news.net/news.asp?idnews=54783.

van der Meer, C. L. J. 2006. Exclusion of small-scale farmers from coordinated supply chains: market failure, policy failure or just economies of scale? Pages 209-217 in R. Ruben, M. Slingerland, and H. Nijhoff, editors. Agro-food chains and networks for development. Springer, Dordrecht, The Netherlands.

van Gelder, J.W., and L. German. 2011. Biofuel finance: global trends in biofuel finance in forest-rich countries of Asia, Africa and Latin America and implications for governance. CIFOR Infobrief 36. Center for International Forestry Research, Bogor, Indonesia. [online] URL: http://www.cifor. org/publications/pdf files/infobrief/3340-infobrief.pdf.

Vermeulen, S., and L. Cotula. 2010. Making the most of agricultural investment: a survey of business models that provide opportunities for smallholders. International Institute for Environment and Development, London, UK. [online] URL: http://pubs.iied.org/12566IIED.html.

von Braun, J., and R. Meinzen-Dick. 2009. Land grabbing by foreign investors in developing countries: risks and opportunities. Policy Brief 13. International Food Policy Research Institute, Washington, D.C., USA. [online] URL: http://www.ifpri.org/sites/default/files/publications/bp013all. pdf.

Zen, Z., C. Barlow, and R. Gondowarsito. 2005. Oil palm in Indonesian socio-economic improvement: a review of options. RSPAS Working Paper 2005-11. Australian National University, Canberra, Australia. [online] URL: http://www.cr awford.anu.edu.au/acde/publications/publish/papers/wp2005/ wp-econ-2005-11.pdf. 